\title{
Penentuan Katagori Wisata Pantai Berdasarkan Data Geologi Menggunakan Metode Fuzzy Mamdani
}

\author{
Arif Suprayitno, Irfan Dwiguna Sumitra \\ Magister Sistem Informasi, Fakultas Pasca Sarjana \\ Universitas Komputer Indonesia \\ Jalan Dipati Ukur no. 112 - 116, Bandung, Jawa Barat, Indonesia \\ $\bigotimes$ : arifs@mgi.esdm.go.id; irfan_dwiguna@unikom.ac.id
}

\begin{abstract}
Abstrak - Bagi investor yang akan memulai menanamkan investasinya di bidang usaha baru tentu sangat membutuhkan pridiksi dengan nilai akurasi yang tinggi tentang besar potensi peluang pasar, juga pridiksi potensi perkembangan bisnisnya, termasuk salah satunya dalam bisnis pengembangan wisata pantai. Fuzzy logic sendiri merupakan salah satu solusi yang tepat untuk memecahkan semua permasalahan ketidakpastian yang ada, sebab fuzzy logic adalah sangat fleksibel dan juga memberikan ruang toleransi terhadap ketidakpresisian semua sifat data. Salah satu bagian dari Fuzzy Inference System yaitu metode fuzzy Mamdani, yang merupakan metode untuk menarik kesimpulan terbaik dari permasalahan yang tidak pasti. Dan dalam penelitian ini fuzzy Mamdani diperlukan untuk mengetahui lebih jauh nilai taksiran tentang katagori wisata pantai berdasarkan data geologi yang ada. Ini diperlukan agar investor dapat meminimalkan kerugian sebelum menamkan investasinya. Adapun data geologi yang menjadi variabel penentu tersebut adalah; kedalaman pantai, tinggi gelombang, besar butir pasir, dan lebar pantai.
\end{abstract}

Kata Kunci - potensi wisata, wisata pantai, fuzzy logic, fuzzy mamdani.

TABEL I

\section{PENDAHULUAN}

Keakuratan nilai takiran dalam sebuah rekomendasi dalam dunia bisnis sangat diperlukan, hal ini agar investor dapat mengurangi peluang gagal dalam berinvestasi. Salah satu nya adalah tentang taksiran penentuan katagori wisata pantai. Salah satu bagian dari Fuzzy Inference System yaitu metode fuzzy Mamdani, yang merupakan metode untuk menarik kesimpulan terbaik dari permasalahan yang tidak pasti (Kusumadewi, 2006). Dalam penelitian ini, metode Fuzzy Mamdani diperlukan untuk menilai katagori wisata pantai berdasarkan dari data geologi pada pantai tersebut.

Ada banyak variabel yang dapat menentukan katagori wisata pantai berdasarkan data geologi yang dimiliki oleh pantai tersebut, namun menurut para pakar pengembangan wisata pantai dan pesisir, ada beberapa variabel utama yang menjadi penentu utama dalam pengkatagorian wisata pantai. Variable tersebut adalah; kedalaman pantai, tinggi gelombang, besar butir pasir, dan lebar pantai.

Masing-masing variabel dari data geologi ini akan digunakan dalam analisa sebagai penetuan katagori pengembangan wisata pantai dengan menggunakan metode fuzzy mamdani. Dalam penelitian ini data yang akan dianalisa sebagai data sample adalah data pantai di beberapa wilayah di seluruh indonesia, data ini berasal dari data penelitian Puslitbang Geologi Kelautan yang sudah dilakukan dari tahun ke tahun. Dengan analisa data geologi pantai ini akan dihasilkan nilai taksiran potensi pantai dari sisi katagori yang

Sesuai untuk dikembangkan sebagai wisata pantai oleh investor. Adapun data pantai yang dimaksud adalah seperti yang terlihat pada tabel 1 di bawah ini;

\begin{tabular}{|l|c|c|c|c|}
\hline \multirow{2}{*}{} & \multicolumn{4}{|c|}{ Data Geologi Pantai } \\
\cline { 2 - 5 } Nama Pantai & $\begin{array}{c}\text { Ke- } \\
\text { dalaman } \\
(\mathrm{m})\end{array}$ & $\begin{array}{c}\text { Tinggi } \\
\text { Gelombang } \\
(\mathrm{m})\end{array}$ & $\begin{array}{c}\text { Besar } \\
\text { Butir } \\
\text { Pasir } \\
(\mathrm{mm})\end{array}$ & $\begin{array}{c}\text { Lebar } \\
\text { Pantai (m) }\end{array}$ \\
\hline Pangkul & 5.5 & 1.75 & 0.004 & 7.5 \\
\hline Batu Hiu & 25 & 1.5 & 0.75 & 7.5 \\
\hline Pangandaran & 15 & 1.85 & 0.75 & 22.5 \\
\hline Samudera Baru & 7.5 & $0.5-1$ & 0.03325 & 7.5 \\
\hline Tanjung Pasir & 7.5 & 1.25 & 0.375 & 15 \\
\hline Yehsanih & 75 & 1.75 & 3 & 5 \\
\hline Karang Kering & 15 & 1.5 & 3 & 7.5 \\
\hline Jungkat & 8 & 0.75 & 0.03325 & 15 \\
\hline Amal Lama & 75 & 1 & 0.03325 & 15 \\
\hline Iboih & 75 & 1 & 160 & 7.5 \\
\hline
\end{tabular}

Data ini yang akan dianalisa menggunakan metode fuzzy mamdani, dengan aturan logic yang berlaku pada saat pemrosesannya. Untuk mendapatkan output dari proses fuzzy mamdani ini, diperlukan 4 tahapan: (1) Pembentukan himpunan fuzzy; (2) Aplikasi fungsi implikasi (aturan); (3) Komposisi aturan,; (4) Penegasan (deffuzy). Ada 3 metode yang digunakan dalam melakukan inferensi sistem fuzzy, yaitu: max, additive, dan probabilistik OR (probor).

a. Metode Max (Maximum)

$\mu_{\mathrm{sf}}[\mathrm{xi}]<-\max \left(\mu_{\mathrm{sf}}[\mathrm{xi}], \mu_{\mathrm{kf}}[\mathrm{xi}]\right)$

dengan:

$\mu_{\text {sf }}[\mathrm{xi}]=$ nilai keanggotaan solusi fuzzy sampai aturan ke-i;

$\mu_{\mathrm{kf}}[\mathrm{xi}]=$ nilai keanggotaan konsekuen fuzzy aturan ke-i;

b. Metode Additive (Sum)

$\mu \mathrm{sf}[\mathrm{xi}]<-\min (1, \mu \mathrm{sf}[\mathrm{xi}]+\mu \mathrm{kf}[\mathrm{xi}])$

dengan: 
$\mu \mathrm{sf}[\mathrm{xi}]=$ nilai keanggotaan solusi fuzzy sampai aturan

ke-i;

$\mu \mathrm{kf}[\mathrm{xi}]=$ nilai keanggotaan konsekuen fuzzy aturan ke-i;

c. Metode Probabilistik OR (probor)

$\mu \mathrm{sf}[\mathrm{xi}]<-(\mu \mathrm{sf}[\mathrm{xi}]+\mu \mathrm{kf}[\mathrm{xi}])-(\mu \mathrm{sf}[\mathrm{xi}] * \mu \mathrm{kf}[\mathrm{xi}])$

dengan:

$\mu \mathrm{sf}[\mathrm{xi}]=$ nilai keanggotaan solusi fuzzy sampai aturan ke-

$\mathrm{i}$

$\mu \mathrm{kf}[\mathrm{xi}]=$ nilai keanggotaan konsekuen fuzzy aturan ke-i;

Menurut Kusumadewi (2004 : 2), bahwa logika fuzzy adalah cara yang tepat untuk memetakan suatu ruang input yang akan diteruskan kedalam suatu ruang output. Fuzzy biasanya dinyatakan dalam derajat dari suatu keanggotaan yang ada dan derajat dari kebenaran.

\section{TINJAUAN PUSTAKA}

\section{A. Fuzzy Mamdani}

Dalam penelitian ini penulis banyak menggunakan referensi sebagai dasar teori dalam pelaksanaan tiap tahapan yang dilakukan, guna untuk lebih memperdalam pengetahuan tentang metode yang digunakan, sehingga tujuan dari penelitian akan lebih mudah untuk diperoleh.

Fuzzy Inference System merupakan sebuah kerangka kerja perhitungan berdasarkan konsep teori himpunan fuzzy dan pemikiran fuzzy yang digunakan dalam penarikan kesimpulan atau suatu keputusan (Kusumadewi, 2006). Penarikan kesimpulan ini diperoleh dari sekumpulan kaidah fuzzy, di dalam Fuzzy Inference System minimal harus terdapat dua buah kaidah fuzzy. Metode Mamdani sering juga dikenal dengan nama Metode Max-Min. Metode ini diperkenalkan oleh Ebrahim Mamdani pada tahun 1975

Adapun metode Fuzzy Mamdani sendiri merupakan salah satu bagian dari Fuzzy Inference System yang berguna sebagai penarikan kesimpulan atau suatu keputusan yang terbaik dalam penyelesaian setiap permasalahan yang tidak pasti (DM.Sukandi, 2013). Metode Fuzzy Mamdani dalam proses penganalisaannya tetap menggunakan kaedah-kaedah linguistik dan memiliki algoritma fuzzy yang dapat dianalisis secara matematis, sehingga akan lebih mudah untuk kita dipahami (Djunaedi.M.,2005). Kelebihan dari Metode Fuzzy Mamdani antara lain adalah lebih spesifik, artinya dalam prosesnya metode fuzzy Mamdani lebih memperhatikan kondisi yang akan terjadi untuk setiap daerah fuzzynya, sehingga dapat menghasilkan hasil keputusan yang lebih akurat (Bova, 2010). Logika fuzzy itu sendiri adalah alat matematika yang kuat untuk mewakili adanya ketidakpastian di segala bidang. Peran logika fuzzy sangat penting bila diterapkan pada fenomena yang kompleks dan yang tidak mudah untuk dijelaskan dengan metode matematika pada umumnya, terutama ketika tujuannya adalah untuk menemukan solusi pendekatan yang baik. Dimana fuzzy set ini telah terbukti menjadi cara yang terkemuka untuk memecahkan masalah terkait keputusan, di mana informasi yang tersedia adalah bersifat subjektif dan jelas (Banerje dan Ghosh, 2013).

\section{B. Konsep Himpunan Fuzzy}

1) Pengertian Himpunan Fuzzy:

Pada himpunan tegas di setiap elemen dalam semestanya akan selalu ditentukan secara tegas apakah elemen itu betul merupakan anggota himpunan tersebut atau bukan, dalam artian lain himpunan fuzzy merupakan suatu kelompok yang mewakili suatu keadaan tertentu dalam suatu variabel fuzzy. Oleh karena itu perlu didefinisikan suatu himpunan fuzzy yang bisa menyatakan kejadian tersebut. Himpunan fuzzy A di dalam semesta pembicaraan U didefinisikan sebagai himpunan yang mencirikan suatu fungsi keanggotaan $(x)$ yang mengawankan setiap $x \in U$ dengan bilangan real di dalam interval $[0,1]$ dengan nilai $\mu A(x)$ menyatakan derajat keanggotaan $\mathrm{x}$ di dalam A. Suatu himpunan fuzzy A dapat dinyatakan dengan dua cara, yaitu :

a. $\quad A=\int u \mu A(x) / x$

Dimana notasi integral melambangkan himpunan semua $x \in U$ bersama dengan derajat keanggotaannya pada himpunan fuzzy A. Cara ini digunakan pada himpunan fuzzy yang anggotanya bernilai kontinu.

b. $A=\Sigma U \mu A(x) / x$

Dimana notasi sigma melambangkan himpunan semua $x \in U$ bersama dengan derajat keanggotaannya pada himpunan fuzzy A. Cara ini digunakan pada himpunan fuzzy yang anggotanya bernilai diskrit.

\section{2) Fungsi Keanggotaan}

Menurut Kusumadewi (2004:8), fungsi keanggotaan adalah suatu kurva yang menunjukkan pemetaan titik - titik input data ke dalam nilai keanggotaannya yang memiliki interval antara 0 sampai 1.

Ada beberapa fungsi yang bisa digunakan. diantaranya, yaitu:

a. Representasi Linear

Pada representasi linear, pemetaan input ke derajat keanggotannya digambarkan sebagai suatu garis lurus. Ada dua keadaan himpunan fuzzy linear, yaitu linear naik dan linear turun. Representasi himpunan fuzzy linear naik seperti yang ditunjukkan pada gambar 1 .

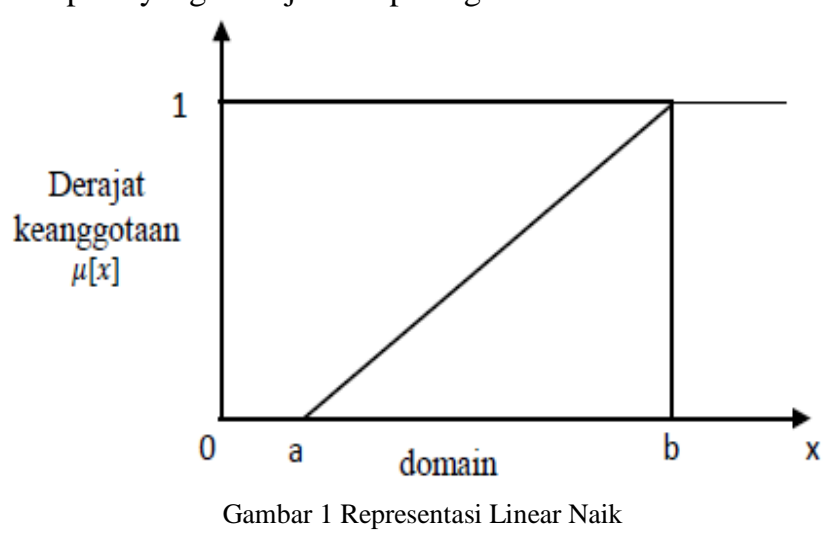

Dimana fungsi keanggotaannya sebagai berikut: 


$$
\mu[x]=\mu[x]=\left\{\begin{array}{rr}
0 ; & x \leq a \\
\frac{(x-a)}{(b-a) ;} & a \leq x \leq b \\
1 ; & x \geq b
\end{array}\right.
$$

\section{Keterangan:}

$\mathrm{a}=$ nilai domain yang mempunyai derajat keanggotaan nol $\mathrm{b}=$ nilai domain yang mempunyai derajat keanggotaan satu $\mathrm{x}=$ nilai input yang akan di ubah ke dalam bilangan fuzzy

\section{b. Representasi Kurva Segitiga}

Kurva Segitiga pada dasarnya merupakan gabungan antara dua garis (linear) seperti terlihat pada gambar 2.

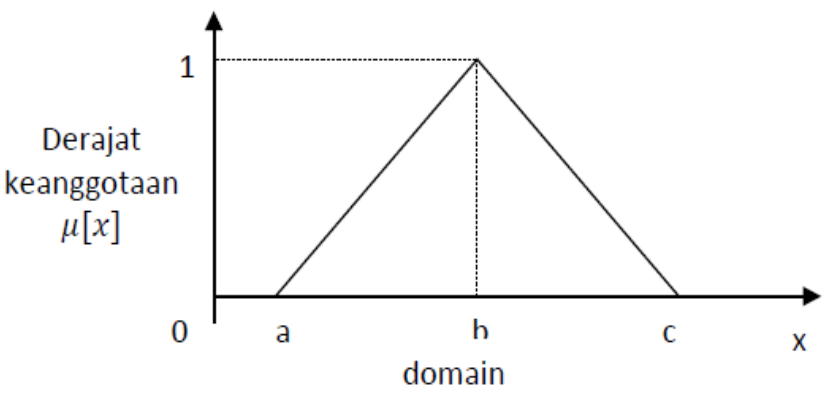

Gambar 2. Representasi Kurva Segitiga

Fungsi Keanggotaan:

Keterangan:

$$
\mu[x]=\left\{\begin{array}{rr}
0 ; & x \leq a \text { atau } x \geq c \\
\frac{(x-a)}{(b-a)} ; & a \leq x \leq b \\
\frac{(c-x)}{(c-b)} ; & b \leq x \leq c
\end{array}\right.
$$

$\mathrm{a}=$ nilai domain terkecil yang mempunyai derajat keanggotaan nol

$\mathrm{b}=$ nilai domain yang mempunyai derajat keanggotaan satu $\mathrm{c}=$ nilai domain terbesar yang mempunyai derajat keanggotaan nol

$\mathrm{x}=$ nilai input yang akan di ubah ke dalam bilangan fuzzy

\section{c. Representasi Kurva Trapesium}

Kurva Trapesium pada dasarnya seperti bentuk segitiga karena merupakan gabungan antara dua garis (linear), hanya saja ada beberapa titik yang memiliki nilai keanggotaan 1. Representasi kurva trapesium ditunjukkan pada gambar 3 .

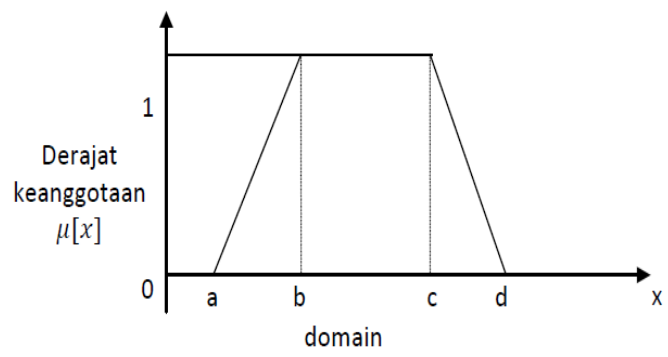

Gambar 3. Representasi Kurva Trapesium

Fungsi Keanggotaan:

$$
\mu[x]=\left\{\begin{array}{lr}
0 ; & x \leq a \text { atau } x \geq d \\
\frac{(x-a)}{(b-a)} ; & a \leq x \leq b \\
1 ; & b \leq x \leq c \\
\frac{(d-x)}{(d-c)} ; & x \geq d
\end{array}\right.
$$

Keterangan:

$\mathrm{a}=$ nilai domain terkecil yang mempunyai derajat keanggotaan nol

$\mathrm{b}=$ nilai domain terkecil yang mempunyai derajat keanggotaan satu

$\mathrm{c}=$ nilai domain terbesar yang mempunyai derajat keanggotaan satu

$\mathrm{d}=$ nilai domain terbesar yang mempunyai derajat keanggotaan nol

$\mathrm{x}=$ nilai input yang akan di ubah ke dalam bilangan fuzzy

\section{d. Representasi Kurva Bahu}

Himpunan fuzzy bahu digunakan untuk mengakhiri variabel suatu daerah fuzzy. Bentuk kurva bahu berbeda dengan kurva segitiga, yaitu salah satu sisi pada variabel tersebut mengalami perubahan turun atau naik, sedangkan sisi yang lain tidak mengalami perubahan atau tetap.

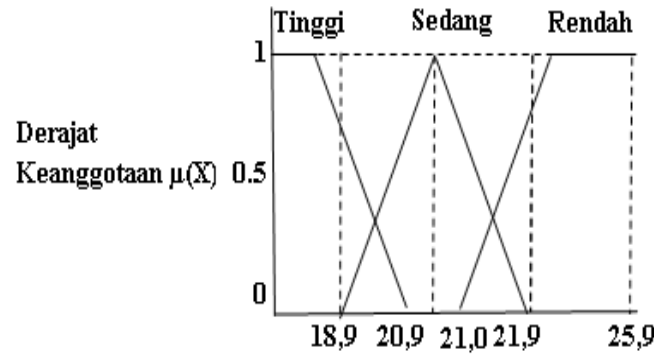

Gambar 4. Represenatsi Kurva Bahu

\section{METODOLOGI PENELITIAN}

Metode yang digunakan dalam penelitian ini adalah Metode Fuzzy Mamdani untuk menghasilkan katagori potensi wisata pantai. Dimana pengkatagorian wisata pantai dibagi menjadi 2 katagori, yaitu: rekreasi, dan katagori wisata pantai lainnya (snorkling, surfing). Sedangkan data yang digunakan untuk penelitian ini adalah data geologi kelautan dari Puslitbang Geologi Kelautan, Dari data-data tersebut dapat 
diperoleh beberapa variabel data, yaitu: batimetri atau kedalaman pantai, besar butir pasir atau karakteristik pantai, tinggi gelombang, dan lebar pantai.

Adapun tahapan yang dilakukan dalam penelitian ini sebagai berikut:

1. Melakukan pengklasifikasian dengan menggunakan metode fuzzy mamdani terhadap data geologi laut

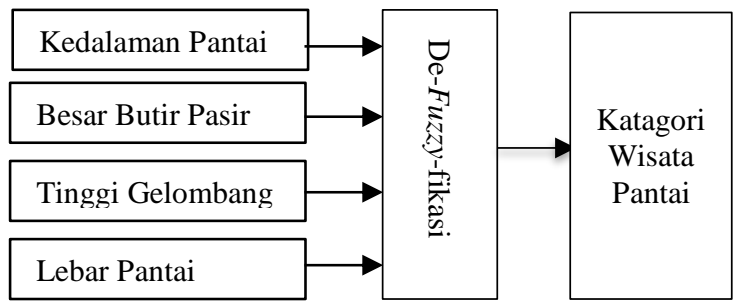

Gambar 5 Pengkatagorian Wisata Pantai

2. Menentukan variable input

Adapun variabel yang dijadikan input dalam menentukan katagori wisata pantai adalah seperti pada tabel II:

TABEL II

VARIABEL INPUT

\begin{tabular}{|c|l|c|}
\hline No & \multicolumn{1}{|c|}{ Variabel } & Satuan \\
\hline 1 & Kedalaman Pantai & Meter \\
\hline 2 & Besar butir pasir & Milimeter \\
\hline 3 & Tinggi Gelombang & Meter \\
\hline 4 & Lebar Pantai & Meter \\
\hline
\end{tabular}

Sementara variabel output menetukan katagori wisata pantai adalah, Katagori Wisata Pantai

3. Membentuk Himpunan Fuzzy

Adapun himpunan fuzzy yang terbentuk dari setiap variabel tersebut adalah sebagai berikut:

a. Kedalaman Pantai

Untuk himpunan fuzzy variabel kedalaman pantai terdapat 3 himpunan, yaitu : dangkal (jika kedalaman < 3 meter), sedang (jika kedalaman 5-10 meter), dan dalam (jika kedalaman $>10$ meter). Himpunn variabel kedalaman tersebut dapat dilihat pada tabel di bawah ini:

TABEL III

VARIABEL KEDALAMAN

\begin{tabular}{|c|c|}
\hline Variabel & Himpunan Fuzzy \\
\hline \multirow{3}{*}{ Kedalaman Pantai } & Dangkal \\
\cline { 2 - 2 } & Sedang \\
\cline { 2 - 2 } & Dalam \\
\hline
\end{tabular}

b. Besar Butir Pantai

Untuk himpunan fuzzy variabel besar butir pasir terdapat 3 himpunan, yaitu: kerikil $(1->64 \mathrm{~mm})$, pasir $(0,125-1 \mathrm{~mm})$, dan lanau $(<0,125 \mathrm{~mm})$. Himpunan fuzzy variabel besar butir pasir dapat dilihat pada tabel IV:
TABEL IV

VARIABEL BESAR PASIR

\begin{tabular}{|c|c|}
\hline Variabel & Himpunan Fuzzy \\
\hline \multirow{3}{*}{$\begin{array}{c}\text { Besar butir } \\
\text { pasir }\end{array}$} & Kerikil \\
\cline { 2 - 2 } & Pasir \\
\cline { 2 - 2 } & Lanau \\
\hline
\end{tabular}

c. Tinggi Gelombang

Untuk himpunan fuzzy variabel tinggi gelombang terdapat 3 himpunan, yaitu: Tinggi $(>1,5)$, Sedang (11,5), dan Rendah (<1). Himpunan fuzzy variabel tinggi gelombang dapat dilihat pada tabel V:

TABEL V

VARIABEL TINGGI GELOMBANG

\begin{tabular}{|c|c|}
\hline Variabel & Himpunan Fuzzy \\
\hline Tinggi & Rendah \\
\cline { 2 - 2 } Gelombang & Sedang \\
\cline { 2 - 2 } & Tinggi \\
\hline
\end{tabular}

d. Lebar Pantai

Untuk himpunan fuzzy variabel lebar pantai terdapat 3 himpunan, yaitu: Sempit (<3), Sedang (3-10), dan Lebar $(>10)$. Himpunan fuzzy variabel lebar pantai dapat dilihat pada table VI:

TABEL VI

VARIABEL LEBAR PANTAI

\begin{tabular}{|c|c|}
\hline Variabel & Himpunan Fuzzy \\
\hline \multirow{3}{*}{ Lebar Pantai } & Sempit \\
\cline { 2 - 2 } & Sedang \\
\cline { 2 - 2 } & Lebar \\
\hline
\end{tabular}

e. Kategori Wisata Pantai

Untuk himpunan fuzzy variabel katagori wisata pantai terdiri 2 himpunan variable, yaitu: katagori Rekreasi (jika besar skor pembobotan $10-12$ ), dan katagori wisata Lainnya (jika besar skor pembobotan 4-9) dapat dilihat pada tabel VII:

TABEL VII

VARIABEL KATEGORI WISATA PANTAI

\begin{tabular}{|c|c|}
\hline Variabel & Himpunan Fuzzy \\
\hline \multirow{2}{*}{ Pilihan } & Rekreasi \\
\cline { 2 - 2 } & Lainnya \\
\hline
\end{tabular}

\section{HASIL DAN PEMBAHASAN}

\section{A. Pembentukan Fungsi Keanggotaan dan Himpunan Fuzzy}

Ini adalah proses menganalisa data geologi pantai yang akan dianalisa untuk mengetahui taksiran katagori wisata pantai dengan data yang ada. Adapun yang dianalisa dari data geologi adalah data variable-variable yang sudah disampaikan di atas.

1) Kedalaman Pantai

Untuk mempresentasikan variabel kedalaman pantai digunakan bentuk kurva bahu kiri untuk himpunan 
fuzzy DANGKAL, bentuk kurva segitiga untuk himpunan fuzzy SEDANG, dan kurva bahu kanan untuk himpunan fuzzy DALAM. Gambar himpunan fuzzy untuk variabel Kedalaman Pantai ditunjukan pada gambar 6:

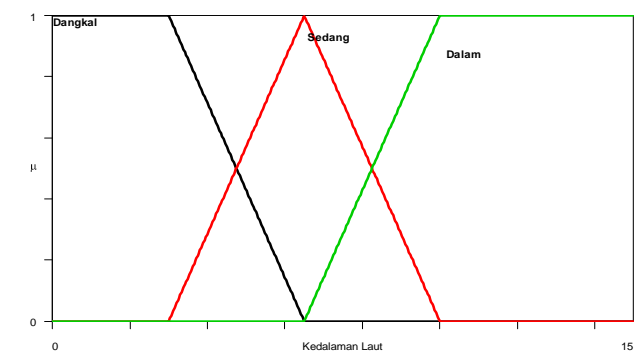

Gambar 6. Grafik Himpunan Keanggotaan Fuzzy Kedalaman Pantai

Dimana sumbu horisontal merupakan nilai input dari variabel kedalaman pantai, sedangkan sumbu vertikal merupakan tingkat keanggotaan dari nilai input. Dengan persamaan fungsi keanggotaan sebagai berikut:

$$
\begin{aligned}
& \mu_{\text {Dangkal }}(x)=\left\{\begin{array}{ccc}
1 & , & x<3 \\
\frac{10-x}{7} & , & 3<x<10 \\
0 & , & x>10
\end{array}\right. \\
& \mu_{\text {Sedang }}(x)=\left\{\begin{array}{cc}
0 & x<3 \\
\frac{x-3}{3.5}, & 3<x<6.5 \\
\frac{10-x}{3.5}, & 6.5<x<10
\end{array}\right. \\
& \mu_{\text {Dalam }}(x)=\left\{\begin{array}{ccc}
0 & , & x<6.5 \\
\frac{x-6.5}{3.5} & , & 6.5<x<10 \\
1 & , & x>10
\end{array}\right.
\end{aligned}
$$

Suatu pantai akan dinilai dangkal apabila dangkal apabila kedalamannya kurang dari 3 meter, dinilai sedang apabila kedalamannya lebih dari 3 meter sampai kurang dari 10 meter, dan dinilai dalam jika kedalamannya lebih dari 10 meter.

\section{2) Besar Butir Pasir}

Pada variabel butir pasir didefinisikan tiga himpunan fuzzy yaitu LANAU, PASIR, dan KERIKIL. Untuk mempresentasikan variabel butir pasir digunakan bentuk kurva bahu kiri untuk himpunan fuzzy LANAU, bentuk kurva segitiga untuk himpunan fuzzy PASIR, dan kurva bahu kanan untuk himpunan fuzzy KERIKIL. Gambar himpunan fuzzy untuk variabel butir pasir ditunjukan pada gambar 7:

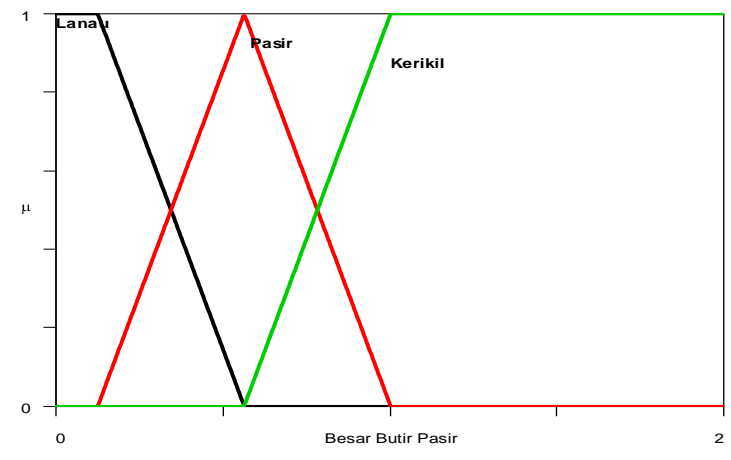

Gambar 7. Grafik Himpunan Keanggotaan Fuzzy Butir Pasir

Dimana sumbu horisontal merupakan nilai input dari variabel butir pasir, sedangkan sumbu vertikal merupakan tingkat keanggotaan dari nilai input. Dengan persamaan fungsi keanggotaan sebagai berikut:

$$
\begin{aligned}
& \mu_{\text {Lanau }}(x)\left\{\begin{array}{ccc}
1 & x<0.125 \\
\frac{0.5625-x}{0.55} & , & 0.125<x<0.5625 \\
0 & , & x>0.5625
\end{array}\right. \\
& \mu_{\text {Pasir }}(x)=\left\{\begin{array}{ccc}
0 & , & x<0.125 \\
\frac{x-0.125}{0.55} & , & 0.125<x<0.5625 \\
\frac{1-x}{5.5} & , & 0.5625<x<1
\end{array}\right.
\end{aligned}
$$

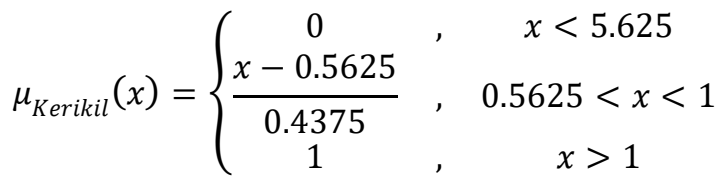

Suatu butir pasir akan dikatakan sebagai lanau apabila ukuran diameter butir pasirnya kurang dari 0.125 milimeter, dikatakan pasir apabila ukuran diameter butir pasirnya lebih dari 0.5625 milimeter sampai kurang dari 1milimeter, dan dikatakan sebagai kerikil jika ukuran diameter butir pasirnya lebih dari 1 milimeter.

\section{3) Tinggi Gelombang}

Pada variabel tinggi gelombang didefinisikan tiga himpunan fuzzy yaitu RENDAH, SEDANG, dan TINGGI. Untuk mempresentasikan variabel tinggi gelombang digunakan bentuk kurva bahu kiri untuk himpunan fuzzy RENDAH, bentuk kurva segitiga untuk himpunan fuzzy SEDANG, dan kurva bahu kanan untuk himpunan fuzzy TINGGI. Gambar himpunan fuzzy untuk variabel tinggi gelombang ditunjukan pada gambar 8: 


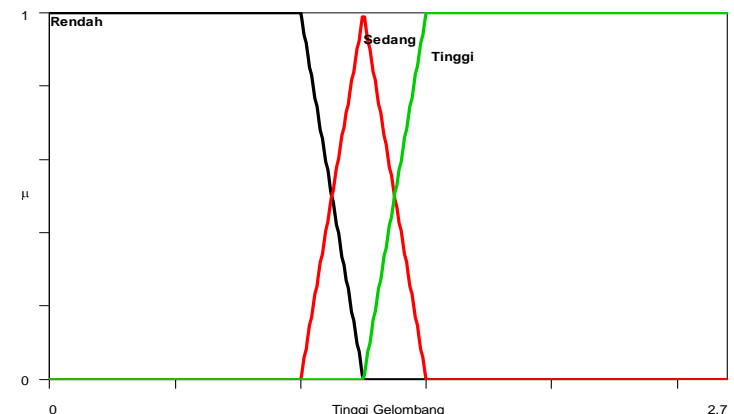

Gambar 8. Grafik Himpunan Keanggotaan Fuzzy Tinggi Gelombang

Dimana sumbu horisontal merupakan nilai input dari variabel tinggi gelombang, sedangkan sumbu vertikal merupakan tingkat keanggotaan dari nilai input. Dengan persamaan fungsi keanggotaan sebagai berikut:

$$
\begin{aligned}
& \mu_{\text {Rendah }}(x)=\left\{\begin{array}{ccc}
1 & , & x<1 \\
\frac{1.25-x}{0.25} & , & 1<x<1.25 \\
0 & , & x>1.25
\end{array}\right. \\
& \mu_{\text {Sedang }}(x)=\left\{\begin{array}{cc}
0 & , \quad x<1 \\
\frac{x-1}{0.25}, & 1<x<1.25 \\
\frac{1.5-x}{0.25}, & 1.25<x<1.5
\end{array}\right.
\end{aligned}
$$

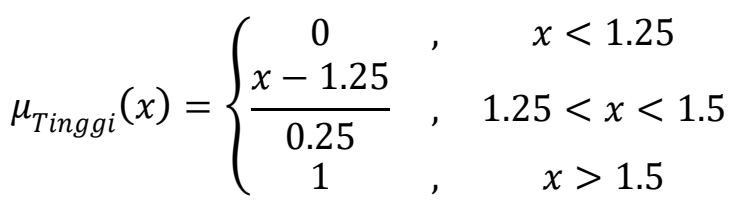

Suatu gelombang akan dikatakan rendah apabila tinggi gelombangnya kurang dari 1 meter, dikatakan gelombang sedang apabila tinggi gelombangnya lebih dari 1 meter sampai kurang dari 1.25 meter, dan dikatakan gelombang tinggi jika ukuran tinggi nya lebih dari 1.5 meter.

\section{4) Lebar Pantai}

Pada variabel lebar pantai didefinisikan tiga himpunan fuzzy yaitu SEMPIT, SEDANG, dan LEBAR. Untuk mempresentasikan variabel lebar pantai digunakan bentuk kurva bahu kiri untuk himpunan fuzzy SEMPIT, bentuk kurva segitiga untuk himpunan fuzzy SEDANG, dan kurva bahu kanan untuk himpunan fuzzy LEBAR. Gambar himpunan fuzzy untuk variabel lebar pantai ditunjukan pada gambar 9:

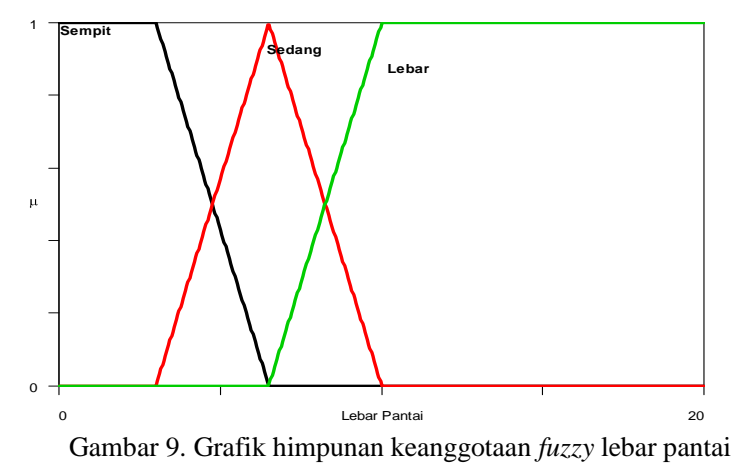

Dimana sumbu horisontal merupakan nilai input dari variabel lebar pantai, sedangkan sumbu vertikal merupakan tingkat keanggotaan dari nilai input. Dengan persamaan fungsi keanggotaan sebagai berikut:

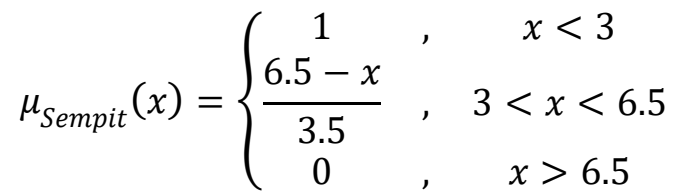

$$
\begin{aligned}
& \mu_{\text {Sedang }}(x)=\left\{\begin{array}{cc}
0, & x<3 \\
\frac{x-3}{3.5}, & 3<x<6.5 \\
\frac{10-x}{3.5}, & 6.5<x<10
\end{array}\right.
\end{aligned}
$$

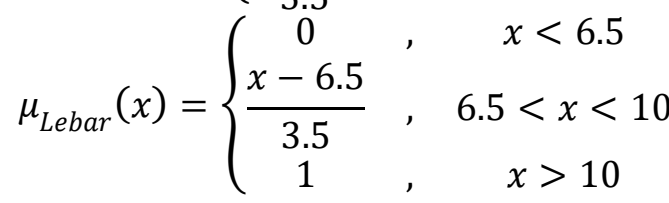

Suatu pantai akan dikatakan sempit apabila lebarnya kurang dari 3 meter, dikatakan lebar pantai sedang apabila lebarnya dari 6.5 meter sampai kurang dari 10 meter, dan lebar jika ukuran luas lebar pantainya lebih dari 10 meter.

\section{5) Kategori Wisata Pantai}

Pada variabel katagori wisata didefinisikan dua himpunan fuzzy yaitu REKREASI, dan LAINNYA. Untuk mempresentasikan variabel katagori wisata digunakan bentuk kurva bahu kiri untuk himpunan fuzzy LAINNYA, , dan kurva bahu kanan untuk himpunan fuzzy REKREASI. Gambar himpunan fuzzy untuk variabel katagori wisata ditunjukan pada gambar 10: 


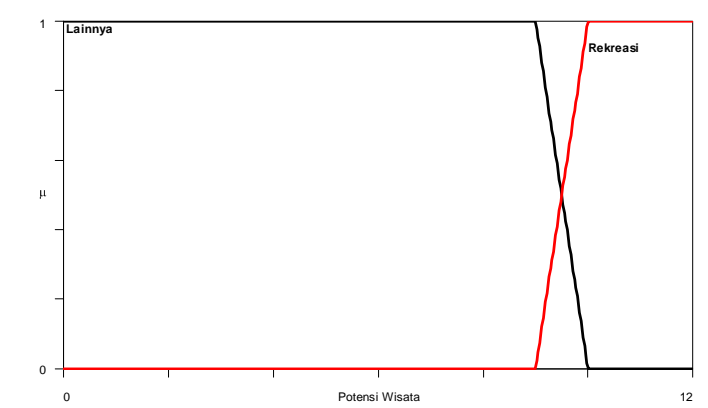

Gambar 10. Grafik himpunan keanggotaan fuzzy katagori wisata

Dimana sumbu horisontal merupakan nilai input dari variabel katagori wisata, sedangkan sumbu vertikal merupakan tingkat keanggotaan dari nilai input. Dengan persamaan fungsi keanggotaan sebagai berikut:

$$
\begin{gathered}
\mu_{\text {Lainnya }}(x)=\left\{\begin{array}{cc}
1, & x<9 \\
\frac{10-x}{1}, & 9<x<10 \\
0, & x>10
\end{array}\right. \\
\mu_{\text {Rekreasi }}(x)=\left\{\begin{array}{cc}
0, & x<9 \\
\frac{x-9}{1}, & 9<x<10 \\
1 & x>10
\end{array}\right.
\end{gathered}
$$

Suatu pantai akan dikatagorikan cocok untuk wisata selain rekreasi apabila skor bernilai kurang dari 9, sedang kan pantai itu dikatagorikan cocok untuk wisata janis rekreasi apabila skor dari pembobotannya bernilai lebih dari 10 meter.

\section{B. Aplikasi Fungsi Implikasi}

Setelah proses pembentukan himpunan fuzzy untuk masing-masing variabel, maka selanjutnya dilakukan pembentukan aturan fuzzy. Aturan - aturan ini dibentuk untuk menyatakan relasi antara input dan output dari hasil proses pembentukan himpunan. Dimana setiap aturan adalah merupakan suatu implikasi. Dan operator yang digunakan untuk menghubungkan antara dua input adalah operator AND, dan operator yang digunakan untuk memetakan antara inputoutput adalah IF-THEN. Proposisi yang mengikuti IF disebut anteseden, sedangkan proposisi yang mengikuti THEN disebut konsekuen. Berdasarkan variabel yang ada, maka dapat dibentuk aturan-aturan sebagai berikut:

[R1]: If (Kedalaman Laut is Dangkal) and (Besar Butir Pasir is Lanau) and (Tinggi Gelombang is Rendah) and (Lebar Pantai is Sempit) then (Potensi Wisata is Bukan Rekreasi)

[R2]: If (Kedalaman Laut is Dangkal) and (Besar Butir Pasir is Lanau) and (Tinggi Gelombang is Rendah) and (Lebar Pantai is Sedang) then (Potensi Wisata is Bukan Rekreasi)
[R3]: If (Kedalaman Laut is Dangkal) and (Besar Butir Pasir is Lanau) and (Tinggi Gelombang is Rendah) and (Lebar Pantai is Lebar) then (Potensi Wisata is Bukan Rekreasi)

[R4]: If (Kedalaman Laut is Dangkal) and (Besar Butir Pasir is Lanau) and (Tinggi Gelombang is Sedang) and (Lebar Pantai is Sempit) then (Potensi Wisata is Bukan Rekreasi)

[R5]: If (Kedalaman Laut is Dangkal) and (Besar Butir Pasir is Lanau) and (Tinggi Gelombang is Sedang) and (Lebar Pantai is Sedang) then (Potensi Wisata is Bukan Rekreasi)

[R6]: If (Kedalaman Laut is Dangkal) and (Besar Butir Pasir is Lanau) and (Tinggi Gelombang is Sedang) and (Lebar Pantai is Lebar) then (Potensi Wisata is Bukan Rekreasi)

[R7]: If (Kedalaman Laut is Dangkal) and (Besar Butir Pasir is Lanau) and (Tinggi Gelombang is Tinggi) and (Lebar Pantai is Sempit) then (Potensi Wisata is Rekreasi)

[R8]: If (Kedalaman Laut is Dangkal) and (Besar Butir Pasir is Lanau) and (Tinggi Gelombang is Tinggi) and (Lebar Pantai is Sedang) then (Potensi Wisata is Rekreasi)

[R9]: If (Kedalaman Laut is Dangkal) and (Besar Butir Pasir is Lanau) and (Tinggi Gelombang is Tinggi) and (Lebar Pantai is Lebar) then (Potensi Wisata is Rekreasi)

[R10]: If (Kedalaman Laut is Dangkal) and (Besar Butir Pasir is Pasir) and (Tinggi Gelombang is Rendah) and (Lebar Pantai is Sempit) then (Potensi Wisata is Bukan Rekreasi) (1)

[R11]: If (Kedalaman Laut is Dangkal) and (Besar Butir Pasir is Pasir) and (Tinggi Gelombang is Rendah) and (Lebar Pantai is Sedang) then (Potensi Wisata is Bukan Rekreasi)

[R12]: If (Kedalaman Laut is Dangkal) and (Besar Butir Pasir is Pasir) and (Tinggi Gelombang is Rendah) and (Lebar Pantai is Lebar) then (Potensi Wisata is Bukan Rekreasi)

[R13]: If (Kedalaman Laut is Dangkal) and (Besar Butir Pasir is Pasir) and (Tinggi Gelombang is Sedang) and (Lebar Pantai is Sempit) then (Potensi Wisata is Bukan Rekreasi)

[R14]: If (Kedalaman Laut is Dangkal) and (Besar Butir Pasir is Pasir) and (Tinggi Gelombang is Sedang) and (Lebar Pantai is Sedang) then (Potensi Wisata is Bukan Rekreasi)

[R15]: If (Kedalaman Laut is Dangkal) and (Besar Butir Pasir is Pasir) and (Tinggi Gelombang is Sedang) and (Lebar Pantai is Lebar) then (Potensi Wisata is Bukan Rekreasi)

[R16]: If (Kedalaman Laut is Dangkal) and (Besar Butir Pasir is Pasir) and (Tinggi Gelombang is Tinggi) and (Lebar Pantai is Sempit) then (Potensi Wisata is Rekreasi) 
[R17]: If (Kedalaman Laut is Dangkal) and (Besar Butir Pasir is Pasir) and (Tinggi Gelombang is Tinggi) and (Lebar Pantai is Sedang) then (Potensi Wisata is Bukan Rekreasi)

[R18]: If (Kedalaman Laut is Dangkal) and (Besar Butir Pasir is Pasir) and (Tinggi Gelombang is Tinggi) and (Lebar Pantai is Lebar) then (Potensi Wisata is Bukan Rekreasi)

[R19]: If (Kedalaman Laut is Dangkal) and (Besar Butir Pasir is Kerikil) and (Tinggi Gelombang is Rendah) and (Lebar Pantai is Sempit) then (Potensi Wisata is Bukan Rekreasi)

[R20]: If (Kedalaman Laut is Dangkal) and (Besar Butir Pasir is Kerikil) and (Tinggi Gelombang is Rendah) and (Lebar Pantai is Sedang) then (Potensi Wisata is Bukan Rekreasi)

[R21]: If (Kedalaman Laut is Dangkal) and (Besar Butir Pasir is Kerikil) and (Tinggi Gelombang is Rendah) and (Lebar Pantai is Lebar) then (Potensi Wisata is Bukan Rekreasi)

[R22]: If (Kedalaman Laut is Dangkal) and (Besar Butir Pasir is Kerikil) and (Tinggi Gelombang is Sedang) and (Lebar Pantai is Sempit) then (Potensi Wisata is Bukan Rekreasi)

[R23]: If (Kedalaman Laut is Dangkal) and (Besar Butir Pasir is Kerikil) and (Tinggi Gelombang is Sedang) and (Lebar Pantai is Sedang) then (Potensi Wisata is Bukan Rekreasi)

[R24]: If (Kedalaman Laut is Dangkal) and (Besar Butir Pasir is Kerikil) and (Tinggi Gelombang is Sedang) and (Lebar Pantai is Lebar) then (Potensi Wisata is Bukan Rekreasi)

\section{Hasil Analisis Defuzzifikasi untuk Kategori Wisata Pantai}

Langkah terakhir dalam proses inferensi Mamdani adalah defuzzifikasi. Input dari proses defuzzifikasi adalah suatu himpunan fuzzy yang diperoleh dari komposisi aturan-aturan fuzzy, sedangkan output yang dihasilkan merupakan suatu bilangan pada domain himpunan fuzzy tersebut. Sehingga jika diberikan suatu himpunan fuzzy dalam range tertentu, maka harus dapat diambil suatu nilai crisp tertentu sebagai output. Metode defuzzifikasi yang paling populer digunakan adalah metode centroid (Coxct, 1999). Pada metode ini, solusi crisp diperoleh dengan cara mengambil titik pusat $\left(\mathrm{z}^{*}\right)$ daerah fuzzy. Secara matematis pusat gravitasi atau center of gravity (COG) dapat dinyatakan menggunakan,

$$
\begin{aligned}
& z^{*}=\frac{\int_{a}^{b} \mu_{A}(z) z d z}{\int_{a}^{b} \mu_{A}(z) d z} \text { untuk variabel kontinu, atau } \\
& z^{*}=\frac{\sum_{z=a}^{b} \mu_{A}(z) z}{\sum_{z=a}^{b} \mu_{A}(z)} \text { untuk variabel diskrit }
\end{aligned}
$$

Dan hasil dari analisa defuzzyfikasi untuk pengkatagorian wisata pantai dari data geologi pantai yang dianalisa menggunakan metode centroid, maka wisata pantai dapat dikatagorikan sebagai berikut seperti pada tabel VIII:
TABEL VIII

SKOR DAN KATEGORI WISATA PANTAI

\begin{tabular}{|c|c|c|l|l|l|l|}
\hline Nama pantai & $\begin{array}{c}\text { Kedalaman } \\
\text { pantai }\end{array}$ & $\begin{array}{c}\text { Butir } \\
\text { pasir }\end{array}$ & $\begin{array}{l}\text { Tinggi } \\
\text { gelombang }\end{array}$ & $\begin{array}{c}\text { Lebar } \\
\text { pantai }\end{array}$ & Skor & Kategori \\
\hline Pangkul & 5.5 & 0.004 & 1.75 & 7.5 & 10.70 & Rekreasi \\
\hline Batu hiu & 25 & 0.75 & 1.5 & 7.5 & 10.67 & Rekreasi \\
\hline Pangandaran & 15 & 0.75 & 1.85 & 22.5 & 6.00 & Lainnya \\
\hline $\begin{array}{c}\text { Samudra } \\
\text { baru }\end{array}$ & 7.5 & 0.03325 & 0.75 & 7.5 & 10.70 & Rekreasi \\
\hline $\begin{array}{c}\text { Tanjung } \\
\text { pasir }\end{array}$ & 7.5 & 0.375 & 1.25 & 15 & 10.67 & Rekreasi \\
\hline $\begin{array}{c}\text { Yehsanih } \\
\text { Karang } \\
\text { kering }\end{array}$ & 75 & 3 & 1.75 & 5 & 10.67 & Rekreasi \\
\hline Jungkat & 8 & 0.03325 & 0.75 & 15 & 10.67 & Rekreasi \\
\hline Amal lama & 75 & 0.03325 & 1 & 1.5 & 10.76 & Rekreasi \\
\hline Iboih & 75 & 160 & 1 & 7.5 & 10.70 & Rekreasi \\
\hline
\end{tabular}

\section{KESIMPULAN}

Dari hasil penelitian ini yang bertujuan untuk mengetahui katagori wisata pantai dengan berdasar data geologi, yang dianalisa menggunakan metode fuzzy mamdani berbasis logika fuzzy maka dapat ditarik kesimpulan sebagai berikut:

1. Logika fuzzy dapat digunakan untuk mengembangkan model dan menganalisa katagori wisata pantai berdasarkan data geologi pantai tersebut.

2. Dari perhitungan metode mamdani didapat katagori wisata pantai untuk dikembangkan menjadi wisata rekreasi atau wisata pantai lainnya.

\section{DAFTAR PUSTAKA}

[1] Kusumadewi, "Perancangan Sistem fuzzy : Studi Kasus Prediksi Jumlah Produksi dan Harga Jual Barang" dalam Jurnal Teknologi Industri Volume 5, No.1. Jogjakarta: Jurusan Teknik Industri Fakultas Teknologi Industri Universitas Islam Indonesia., 2000.

[2] Kusumadewi, Aplikasi Logika Fuzzy untuk Pendukung Keputusan. Yogyakarta: Graha Ilmu, 2004.

[3] Kusumadewi, S., \& Purnomo, H. Aplikasi Logika Fuzzy Untuk Pendukung Keputusan Edisi 2. Yogyakarta: Graha Ilmu., 2010.

[4] D. M. Sukandy, A. T. Basuki, S. Puspasari, "Penerapan Metode Fuzzy Mamdani untuk Memprediksi Jumlah Produksi Minyak Sawit Berdasarkan Data Persediaan dan Jumlah Permintaan(Studi Kasus PT Perkebunan Mitra Ogan Baturaja)",2013.

[5] Yulius.BRKP-DKP, Aplikasi Sistem Informasi Geografis Dalam Penentuan Kawasan Wisata Pantai Kategori Rekreasi Di Teluk Bungus, Kota Padang, 2004.

[6] Coxct, E., The Fuzzy Systems Handbook: A Practitioner's Guide to Building, Using, and Maintaining Fuzzy Systems, 2nd edition. Academic Press, San Diego, CA. 1999.

[7] Ablhamid, R. K., Santoso, B., \& Muslim, M. A., Decision Making And Evaluation System For Employee Recruitment Using Fuzzy Analytic Hierarchy Process. Interational Refereed Journal Of Engineering And Science (IRJES) ISSN (Online) 2319-183X, (Print) 2319-1821 Volume 2, Issue 7, 1-8. 2013.

[8] Banerjee, R., \& Ghosh, D. N. Faculty Recruitment In Engineering Organization Through Fuzzy MultiCriteria Group Decision Making Methods. International Journal Of U- And E- Science And Technology, 116. 2013.

[9] Kaur, A., \& Kaur, A. Comparison Of Mamdani-Type And Sugeno-Type Fuzzy Inference System For Air Conditioning System. International 
Journal Of Soft Computing And Engineering (IJSCE) ISSN: 2231-2307, Volume-2, Issue-2, 1-3, 2012.

[10] Poonam. Uncertainty Handlin Fuzzy Logic In Rule Based System. International Journal Of Advanced Science And Technology Vol. 45, 1 16, 2012.

[11]Cincin-Sain B., and Robert W.B. Integrated Coastal and Ocean Management. Concepts and Practices. Island Press Washington, DC. Covello,California, 2013.

[12] Nithya, R., \& Santhi, B. Classification of Normal and Abnormal Patterns in Digital Mammograms for Diagnosis of Breast Cancer. International Journal of Computer Applications. Vol 28. No 6.Alayón, S., Roberston, R. K., Warfield, S., Ruiz-Alzoa, J., (2007). A Fuzzy System for Helping Medical Diagnosis of Malformations of Cortical Development. Journal Biomedical Information, 40 (3), 221-235, 2011.

[13] Khanale, P. B., Ambilwade, R. P., A Fuzzy Inference System for Diagnosis of Hypothyroidism. Jurnal of Artificial Intelligence 4 (1), 45 $54,2011$.

[14]Maramin. 2004. Teknik dan Aplikasi Pengambilan Keputusan Kriteria Majemuk. Jakarta : PT Gramedia Widiasarana Indonesia.

[15]Puslitbang Geologi Kelautan. Penelitian Geologi Pantai Jawa Timur, 2003.

[16]Badan Koordinasi Survey dan Pemetaan Nasional. (1996). Pengembangan Protipe Wilayah Pesisir dan Marine Kupang Nusa Tenggara Timur. Pusat Bina Aplikasi Inderaja dan SIG. Cibinong.

[17]Dahuri R. 2003. Keanekaragaman Hayati Laut, Aset Pembangunan Berkelanjutan Indonesia. PT Gramedia Pustaka Utama. Jakarta.

[18]Eka Noerma Yulisa. (2013). Analisis Kesesuaian Dan Daya Dukung Ekowisata Pantai Kategori Rekreasi Pantai Laguna Desa Merpas Kabupaten Kaur. Jurnal Enggano Vol. 1, No. 1, April 2016: 97-111.

[19] Sarah Nicholls. Agent-Based Modeling: A Powerful Tool for Tourism Researchers. Journal of Travel Research, Vol. 56 (I), 3-5, 2017.

[20]A. Yaniarsyah Hasan. Analisis Biaya Modal Terhadap Tingkat Pengembalian Investasi Pada Pt. Harimugabe Jaya. Jurnal Ilmiah WIDYA, Vol. 1 No. 1, 45-51, 2013.

[21]Juliana. Kesesuaian Dan Daya Dukung Wisata Bahari Di Perairan Bandengan Kabupaten Jepara Jawa Tengah. Jurnal Perikanan dan Kelautan Tropis Vol. IX-1, April 2013., 2016.

[22] Ashfa Durri. (2016). Analisis Kelayakan Usaha Dalam Rangka Rencana Pengembangan Usaha (Studi Kasus Pada Po. Zena Pariwisata Malang). Jurnal Administrasi Bisnis (JAB), Vol.35 No.2, 174-180. 